\title{
Beef for baby food from bulls and castrates
}

\author{
Nikolay Zabashta ${ }^{1}$, Elena Golovko ${ }^{1, *}$, Irina Sinelshchikova ${ }^{1}$ and Anastasia \\ Visokopoyasnaya ${ }^{1}$ \\ ${ }^{1}$ Krasnodar research centre for animal husbandry and veterinary medicine, 4, Pervomayskaya str., \\ 350055, Znamensky village, Krasnodar, Russia
}

\begin{abstract}
The research was conducted to compare bulls and castrates in relation to the morphological composition of carcasses, the yield of beef suitable for the production of baby food products, and the quality and safety of raw meat. The research was based on the results of monitoring the safety of the environment, feed, and meat raw materials during the growing and fattening of steers with a meat productivity direction. The preslaughter weight and the yield of lean beef of 16-month-old Hereford bullcalves are higher in comparison with castrated animals of the same age, by 6.4 and $1 \%$, respectively. The muscle tissue of castrates contained $11.5 \%$ of fat, and bulls $-9.7 \%$. The protein content in the longest muscle of bulls was $19.8 \%$, and in castrates-17.0. The amount of fat beef that is not suitable for baby food is higher in castrate carcasses by $4.7 \%$ compared to bull calves. A high protein quality index of the longest muscle of bulls (6.5) indicates a higher biological value of beef compared to meat from castrates (4.1). In terms of the content of residual amounts of pesticides, toxic elements, and antibiotics, the meat of castrates and bulls of the Hereford breed had no significant differences.
\end{abstract}

\section{Introduction}

Meat productivity of animals closely related to biological status. For fattening beef bulls with pronounced meat qualities and getting lean beef suitable for the production of baby food products, you need to choose not only the slaughter age, but also between bulls and castrates [1-5]. Italian beef management is usually bases on entire males, since they show better growth rate and higher lean yield carcasses. Despite consumer's preferences require lean meat, producers have been inducing to consider the positive effect of castration especially on meat organoleptic traits [6-8].

There are conflicting opinions on this issue. The results of the study by the authors of the Bashkir Agricultural University indicate the influence of the genotype and physiological state of animals on their meat qualities, regardless of sexual status.

Crossbred bulls and castrates demonstrated the advantage, both in quantitative and qualitative indicators.

There are author's data on differences in meat productivity and beef quality between castrates and bulls of the same breed.

\footnotetext{
* Corresponding author: martinija@yandex.ru
} 
There are differences in the content of fat in muscle tissue. The content of fat cells in the connective tissue layers studied by the authors as part of the longest muscle of Kalmyk castrates was significant. According to some researchers, bull meat has a higher waterholding capacity compared to castrates.

Significant differences in the physical and chemical characteristics of the muscle tissue of castrated and intact bulls were also found [9-10].

In this regard, comparative studies were carried out in accordance with the methodological principles for evaluating meat productivity and quality of cattle meat [11].

There are author's data on differences in meat productivity and beef quality between the castrates and bulls of the same breed.

There are differences in the fat content in muscle tissue. The content of fat cells in the layers of connective tissue which was studied by the authors as part of the longest muscle of castrates of the Kalmyk breed was significant.

According to some researchers, the meat of bulls has a higher water-holding ability compared to castrates. Significant differences were also found in the physicochemical characteristics of the muscle tissue of castrated and non-castrated bulls [12-14].

In this regard, comparative studies were carried out in accordance with the methodological principles for assessing meat productivity and meat quality in cattle [15]. The aim of the study was to compare the productivity, quality and safety of meat raw materials of castrates and bulls of Hereford breed in order to determine its suitability for the production of baby food. The Agro Industrial Complex Otradnenskaya LLC selected the meat productivity of bulls and castrates of Hereford breed, the quality and environmental suitability (safety) of beef for the production of baby food as objects of study.

\section{Materials and methods}

The farms that supply raw meat for baby food products are the place to study the effect of the sexual status (castrates, bulls) of cattle on meat productivity, quality and environmental safety of the suitability of beef for baby food.

The studies were based on the results of monitoring the safety of the environment, feed, meat raw materials obtained during the growing and fattening of beef bulls.

Young animals were raised according to the technology of specialized beef cattle breeding : up to 6 months of age under the nurse's mothers (cow - calf).

The castration was performed at the age of 6 months. After weaning and up to 16 months, bulls and castrates were kept on a feedlot with a paddock. The bulls and castrates were kept in groups, loose. The animals were fed and watered in the walking and feeding yard under a canopy. At the age of 16 months castrates (live weight $382.3 \pm 5.7 \mathrm{~kg}$ ) and bulls (live weight $406.7 \pm 6.0 \mathrm{~kg}$ ) of the Hereford breed $(n=12)$ were slaughtered. The morphological composition of bull and castrate carcasses and the yield of meat suitable for the production of baby food were studied in a comparative aspect.

\section{Results and discussion}

Pre-slaughter live weight 16 months castrates and bulls of the Hereford breed of compact type in LLC "Agro Industrial Company Otradnenskaya", the Otradnaya station of the Krasnodar Territory amounted, respectively, to $382.3 \pm 5.2$ and $406.7 \pm 4.0 \mathrm{~kg}$, i.e. bulls by weight exceeded castrates of the same age by $24 \mathrm{~kg}$ (table 1). 
Table 1. Meat productivity of Hereford castrates and bulls $(X \pm m), n=12$.

\begin{tabular}{|l|c|c|}
\hline \multirow{2}{*}{\multicolumn{1}{|c|}{ Indicators }} & \multicolumn{2}{c|}{ Biological status } \\
\cline { 2 - 3 } & castrates & bulls \\
\hline \multicolumn{1}{|c|}{$\%$} & $382.3 \pm 5.2$ & $406.7 \pm 4.0^{\mathrm{a}}$ \\
\hline Pre-slaughter weight, $\mathrm{kg}$ & 100.0 & 106.4 \\
\hline Weight of the fresh carcass, $\mathrm{kg}$ & $199.3 \pm 1.5$ & $210.7 \pm 2.2^{\mathrm{a}}$ \\
\hline Weight of chilled carcass, $\mathrm{kg}$ & $196.7 \pm 3.4$ & $205.2 \pm 3.8$ \\
\hline $\begin{array}{l}\text { Including boneless beef } \\
\text { for baby food, kg }\end{array}$ & $120.4 \pm 3.4$ & $127.7 \pm 3.7$ \\
\hline Boneless beef for baby food, \% & 61.2 & 62.2 \\
\hline Including beef boneless fat, $\mathrm{kg}$ & $26.4 \pm 1.7$ & $17.9 \pm 1.2^{\mathrm{a}}$ \\
\hline Boneless fat, \% & 13.4 & 8.7 \\
\hline Raw fat, kg & $1.5 \pm 1.4$ & $2.2 \pm 1.5$ \\
\hline Connective tissue, $\mathrm{kg}$ & $2.9 \pm 0.5$ & $2.5 \pm 0.7$ \\
\hline Bones, kg & $20.3 \pm 1.2$ & $22.28 \pm 0.9^{\mathrm{a}}$ \\
\hline Technical stripping, $\mathrm{kg}$ & $2.2 \pm 0.2$ & $2.1 \pm 0.3$ \\
\hline Bones to carcass weight, \% & 21.5 & 22.4 \\
\hline
\end{tabular}

Note: ${ }^{\mathrm{a}}-\mathrm{p}<0,05$.

The weight of the cooled carcass in bulls was higher $(205.2 \pm 3.8 \mathrm{~kg})$ compared to castrates (196.7 \pm 3.4$)$.

The yield of boneless beef for baby food in bulls $(127.7 \pm 3.7 \mathrm{~kg})$ is also significantly higher than in castrates $(120.4 \pm 3.4 \mathrm{~kg})$, and in percentage of the mass of the cooled carcass, respectively, 62.2 and $61.2 \%$.

Fat beef, which is not suitable for baby food, was received significantly less from bulls (by $32.2 \%$ ) than from castrates.

Meat for baby food differs significantly from castrates and bulls in terms of fat and protein in the composition of the longest back muscle (table. 2).

Table 2. Physical and chemical composition of the longest muscle (longissimus dorsi) for 16 month castrates and Hereford bulls, $\mathrm{n}=12$.

\begin{tabular}{|l|c|c|}
\hline \multirow{2}{*}{\multicolumn{1}{|c|}{ Indicators }} & \multicolumn{2}{c|}{ Biological status } \\
\cline { 2 - 3 } & castrates & bulls \\
\hline Mass fraction of moisture, \% & 70.5 & 69.4 \\
\hline Mass fraction of protein, \% & 17.0 & $19.8^{\mathrm{a}}$ \\
\hline Mass fraction of fat, \% & 11.5 & $9.7^{\mathrm{a}}$ \\
\hline Mass fraction of ash, \% & 1.0 & 1.1 \\
\hline The color intensity of Extinction *1000 & 75.45 & $82.5^{\mathrm{a}}$ \\
\hline $\mathrm{pH}$ & 5.7 & $5.9^{\mathrm{a}}$ \\
\hline Including collagen + elastin & 1.9 & 1.8 \\
\hline Tryptophan, mg / 100 g of meat & 260.00 & 320.00 \\
\hline Oxyproline, mg / 100 g of meat & 63.4 & 49.23 \\
\hline $\begin{array}{l}\text { Protein quality index (ratio of the content of } \\
\text { tryptophan and oxyproline) }\end{array}$ & & 6.1 \\
\hline
\end{tabular}

Note: ${ }^{\mathrm{a}}-\mathrm{p}<0,05$.

The studies have shown that in terms of the chemical composition, the muscle tissue of bulls contained more protein (by 2.8 percent) and less fat. The muscle tissue of castrates contained $11.5 \%$ of fat and that of bulls $-9.7 \%$.

The protein content in the longest muscle of bulls was $19.8 \%$, and in castrates-17.0. 
The protein quality index (the ratio of tryptophan and oxyproline content) is significantly higher in bulls (6.5) compared to castrates (4.1), which indicates a higher biological value of beef.

According to the authors, the protein quality index of the longest back muscle of castrates is 4.6 and of bulls - up to 6.7.

The hydrogen index-pH is an important technological characteristic, which was more optimal for bulls - 5.9.

The colour intensity is closely related to the index of hydrogen ion activity.

It is significantly higher in the muscle tissue of bulls (82.5) compared to castrates (75.45), which indicates the best technological properties of beef from bulls.

The quality of protein for baby food products was determined by the degree of balance of their amino acid composition and compliance with the standard - female breast milk.

Studies of the amino acid composition of the meat of bulls and castrates have shown that the rate of such essential amino acids as lysine, histidine and phenylalanine was more than $100 \%$ in relation to the standard - women's milk.

Leucine $(73.7 \%)$ and Valine $(80.9 \%)$ were the limiting amino acids in castrates (table.3).

The limiting amino acids in bulls are Valine (82.0\%) and isoleucine $(82.2 \%)$.

Table 3. Amino Acid score of the longest muscle (longissimus dorsi) of Hereford bulls and castrates in relation to the standard-breast milk, $\%(\mathrm{n}=12)$.

\begin{tabular}{|l|c|c|c|c|c|}
\hline \multirow{2}{*}{ Amino acid (essential) } & \multirow{2}{*}{$\begin{array}{c}\text { Standard } \\
\text { (breast } \\
\text { milk), }\end{array}$} & $\begin{array}{c}\text { mg / kg } \\
\text { dry } \\
\text { mg / kg }\end{array}$ & matter & score, \% & mg / kg dry \\
matter & score, \% \\
\hline Histidine & 26.0 & 38.9 & 149.6 & 40.4 & 155.4 \\
\hline Isoleucine & 46.0 & 37.8 & 82.2 & 33.9 & 73.7 \\
\hline Leucine & 93.0 & $84, .1$ & 90,4 & 80,1 & 86,1 \\
\hline Lysine & 66.0 & 85.4 & 129.4 & 80.1 & 121.4 \\
\hline Methionine + Cystine & 42.0 & 38.0 & 90,5 & 38,3 & 91.2 \\
\hline Phenylalanine + Tyrosine & 72.0 & 75.9 & 105.4 & 73.8 & 102.5 \\
\hline Threonine & 43.0 & 39.8 & 92.6 & 39.5 & 91.9 \\
\hline Tryptophan & 17.0 & 16.6 & 97.6 & 16.5 & 97.5 \\
\hline Valine & 55.0 & 45.1 & 82.0 & 44.5 & 80.9 \\
\hline
\end{tabular}

The mineral composition of the muscle tissue of bulls and castrates differs in some elements: the meat of bulls has more phosphorus, magnesium, iron, copper, selenium, Iodine and cobalt (table. 4).

These trace elements are necessary for the immune system of the child's body.

Table 4. Content of macro-and microelements in the longest muscle (longissimus dorsi) of Hereford bulls and castrates $(\mathrm{X} \pm \mathrm{m}), \mathrm{n}=12$.

\begin{tabular}{|l|c|c|}
\hline \multirow{2}{*}{\multicolumn{1}{|c|}{ Mineral element }} & \multicolumn{2}{c|}{ Biological status } \\
\cline { 2 - 3 } & Castrates & Bulls \\
\hline Potassium, g/ kg & $3.23 \pm 0.8$ & $2.98 \pm 0.8$ \\
\hline Phosphorus, g/ kg & $1.07 \pm 0.01$ & $1.36 \pm 0.04^{*}$ \\
\hline Sodium, $\mathrm{g} / \mathrm{kg}$ & $0.81 \pm 0.2$ & $0.61 \pm 0.3$ \\
\hline Magnesium, $\mathrm{g} / \mathrm{kg}$ & $0.13 \pm 0.1$ & $0.19 \pm 0.1^{*}$ \\
\hline Calcium, $\mathrm{g} / \mathrm{kg}$ & $0.13 \pm 0.01$ & $0.12 \pm 0.01$ \\
\hline Zinc, $\mathrm{mg} / \mathrm{kg}$ & $30.13 \pm 1.10$ & $32.35 \pm 1.10$ \\
\hline Iron, $\mathrm{mg} / \mathrm{kg}$ & $17.8 \pm 1.4$ & $26.30 \pm 3.7^{*}$ \\
\hline
\end{tabular}




\begin{tabular}{|l|c|c|}
\hline Copper, $\mathrm{mg} / \mathrm{kg}$ & $5.2 \pm 0.1$ & $8.3 \pm 0.1^{*}$ \\
\hline Manganese $\mathrm{mg} / \mathrm{kg}$ & $0.10 \pm 0.01$ & $0.13 \pm 0.02$ \\
\hline Iodine, $\mathrm{mg} / \mathrm{kg}$ & $0.025 \pm 0.01$ & $0.035 \pm 0.01^{*}$ \\
\hline Selenium, $\mathrm{mg} / \mathrm{kg}$ & $0.021 \pm 0.01$ & $0.026 \pm 0.01^{*}$ \\
\hline Cobalt, $\mathrm{mg} / \mathrm{kg}$ & $0.020 \pm 0.01$ & $0.025 \pm 0.01^{*}$ \\
\hline
\end{tabular}

Note: $*$ - $\mathrm{p}<0,05$.

According to safety indicators, namely, the content of residual amounts of toxic elements, antibiotics, pesticides, mycotoxins, hormonal drugs, radioactive substances, the meat of castrates and Hereford bulls did not have significant differences and met the safety requirements for baby food (table. 5).

The results of environmental objects monitoring obtained in the raw material zone of meat suppliers (LLC "Agro Industrial Company Otradnenskaya", the Otradnaya station of the Krasnodar Territory) confirm its environmental safety.

Our results are close to the data of early studies of authors who conducted monitoring in the Stavropol Territory, Rostov region and the Republic of Kalmykia of the Russian Federation (research data on raw material zones of the branch "Factory of children's Canned Meat "Tikhoretsky" JSC «DANON Russia".

Table 5. Residual amounts of toxic substances in meat (average minced beef sample) of 16-monthold castrates and Hereford bulls.

\begin{tabular}{|c|c|c|}
\hline \multirow{2}{*}{ Name of the environmental safety indicator } & \multicolumn{2}{|c|}{$\begin{array}{c}\text { Ground beef for the production of } \\
\text { baby food products }\end{array}$} \\
\hline & castrates & bulls \\
\hline \multicolumn{3}{|l|}{ Toxic element: } \\
\hline Lead, mg / kg & $0.040 \pm 0.03$ & $0.035 \pm 0.03$ \\
\hline Cadmium, mg / kg & $<0.01$ & $<0.01$ \\
\hline Mercury, mg / kg & $<0.005$ & $<0.005^{*}$ \\
\hline Arsenic, mg / kg & $<0.0025$ & $<0.0025^{*}$ \\
\hline \multicolumn{3}{|l|}{ Antibiotics: } \\
\hline Tetracycline group, units/g & $<0.01 *$ & $<0.01^{*}$ \\
\hline Bacitracin, units/g & $<0.02 *$ & $<0.02 *$ \\
\hline Levomycetin (chloramphenicol), $\mathrm{mg} / \mathrm{kg}$ & $<0.0003^{*}$ & $<0.0003 *$ \\
\hline Streptomycin, mg / kg & $<0,2 *$ & $<0.2 *$ \\
\hline Penicillin, $\mathrm{mg} / \mathrm{kg}$ & $<0.0025^{*}$ & $<0.0025^{*}$ \\
\hline \multicolumn{3}{|l|}{ Pesticides: } \\
\hline Hexachlorocyclohexane $(\alpha, \beta, \gamma$-isomers), $\mathrm{mg} / \mathrm{kg}$ & $<0.004^{*}$ & $<0.004^{*}$ \\
\hline $\begin{array}{l}\text { (1,1,1-trichloro-2,2-bis(4-chlorophenyl) ethane and its } \\
\text { metabolites, mg/kg }\end{array}$ & $<0.004 *$ & $<0.004^{*}$ \\
\hline $\begin{array}{l}\text { Other pesticides, } \mathrm{mg} / \mathrm{kg} \text { (heptachlor, karbofos, metaphos, } \\
\text { basudin, phosphamide, 2,4-D amine salt) }\end{array}$ & $\begin{array}{c}\text { below the detection } \\
\text { limit }\end{array}$ & \\
\hline Mycotoxins: Aflatoxin $\mathrm{B}_{1}, \mathrm{mg} / \mathrm{kg}$ & $<0.0005^{*}$ & $<0.0005^{*}$ \\
\hline Dioxins, $\mathrm{mg} / \mathrm{kg}$ & $\begin{array}{c}\text { below the detection } \\
\text { limit }\end{array}$ & \\
\hline Hormonal preparation, $\mathrm{mg} / \mathrm{kg}$ & $\begin{array}{c}\text { below the detection } \\
\text { limit }\end{array}$ & \\
\hline \multicolumn{3}{|c|}{ Radionuclides, $\mathrm{Bq} / \mathrm{kg}$} \\
\hline Caesium 137 & 2.2 & 2.0 \\
\hline Strontium 90 & - & - \\
\hline
\end{tabular}

Note: *- the residual amount is below the detection limit of the method. 


\section{Conclusion}

Raw meat from castrates and bulls of the Hereford breed at the age of 16 months meets the requirements of the technical regulations for raw materials for baby food. Beef is environmentally safe.

From non-castrated bulls, the yield of lean beef suitable for the production of baby food products was higher by $1.0 \%$ compared to castrates.

The amount of fat beef, which is not suitable for use in the production of baby food, was $4.7 \%$ higher in the castrate carcasses compared to bulls of the Hereford breed at the age of 16 months, which meets the requirements of the technical regulations for raw materials for baby food.

According to the standard for baby food, the fat content in muscle tissue should not exceed $10 \%$. In the longest back muscle of steer's carcasses, the fat content met the standard and amounted to $9.5 \%$.

In the longest muscle of castrate carcasses, the fat content was $11.5 \%$, which is not significantly higher than the amount allowed by the standard.

A high protein quality index of the longest muscle of bulls (6.5) indicates a higher biological value of beef compared to meat from castrates (4.1).

\section{References}

1. J. Rodriguez, J. Unruh, M. Villarreal-Castro, O. Murillo, Meat Science 96(3),13401344 (2013) DOI: 10.1016/j.meatsci.2013.10.024

2. R. Aydin, M. Yanar, A. Diler, R. Kocyigit, N. Tuzemen, Indian Journal of Animal Research 47, 10-16 (2013)

3. N.V. Konik, L.N. Skorykh, O.A. Shutova et al., Research journal of pharmaceutical, biological and chemical sciences 9(4), 607-612 (2018)

4. S.V. Patieva, A.M. Patieva, E.P. Lisovitskaya, N.N. Zabashta, Research Journal of Pharmaceutical, biological and chemical sciences 7(2), 731-737 (2016)

5. S. Segato, C. Elia, C. Mazzini, C. Bianchi, I. Andrighetto, J. of Anim. Sci. V 4 (2010) DOI: 10.4081/ijas.2005.2s.263

6. S. Marti, C. Realini, A. Bach, M. Perez Juan, M. Devant, J. of Anim. Sci. VL 91 (2014) DOI: $10.2527 /$ jas.2012-5717

7. H. Lim, J.S. Ahn, J.M. Kim, G.H. Son et al., Journal of Anim. Sci. and Tech. 60 (2018)

8. J.K. Cheong, Y.T. Oh, H.N. Choi, C.H. Lee et al., J Anim. Sci. Technol. 54(2), 47-52 (2012)

9. Ministry of Agriculture, Food and Rural Affairs (MAFRA). Grade rule for cattle carcass in Korea. Korea Ministry of Government Legislation, http://www.law.go.kr/main.htm

10. J. Becker, M.G. Doherr, R.M. Bruckmaier et al., The Veterinary Journal 194, 380-385 (2012)

11. S. Amatayakul-Chantler, F. Hoe, J.A. Jackson et al., Brazil Meat Science 95, 78-84 (2013)

12. A.F. Shevkhuzhev, F.G. Kayumov, N.P. Gerasimov, D.R. Smakuev, Research Journal of Pharmaceutical, Biological and Chemical Sciences 8(5), 634-641 (2017) 
13. A.C.G. Monteiro, D.R. Navas, J.P.C. Lemos, Cambridge University Press V8(4), 675682 (2014) DOI: https://doi.org/10.1017/S1751731114000196

14. Y. Nian, P. Allen, S.M. Harrison, J.P. Kerry, J Sci. Food Agric. 98(11), 4339-4350 /08/02 (2018)

15. J. Rodriguez, J. Unruh, M. Villarreal, et al. Costa Rica Meat Sci. 96(3), 1340-1344 (2014) 